\title{
Strategizing in the context of opportunities
}

Aleksandra Sus, Ph.D. Eng. Wroclaw University of Economics, Department of Strategy and Management Methods

\section{Introduction}

Increasingly more attention of strategic management researchers is given to formulating micro level strategies, which emphasizes the role of organizational actors and their activity. The foundation of the strategy, its cornerstone and the creator is no longer an impersonal organization, but a man. In this way, after many years of exile from strategic management studies, we are observing a gradual return to anthropomorphisation of market entities. As emphasized by G. Johnson, L. Melin and R. Whittington: research on the strategy should primarily concern activities of individuals, groups and networks between people, which determine key strategic processes (2003, p. 14). An individual therefore gains crucial importance, and with it comes a new nomenclature with the terms microactions, microaspects and microfundations. The micro-phenomenon of re-drawing the attention of theoreticians and practitioners towards an individual is a direct consequence of the surge in popularity of human resources in management sciences (although chronological analysis indicates the blending of these two trends) and an increase in the 
relevance of human capital. However, the micro-trend has primarily been popularized thanks to the SAP-IN researchers ${ }^{1}$.

Analysing the strategic problems of the micro level (strategizing) in the context of opportunity (environment - context) and seeking to identify their individual determinants are among the main motives of this study. The aim of the research is to identify the relationship in the dyad: Individual differentiators (micro level) - opportunities (macro level), or an attempt to present a section of relations between the interior and the environment of modern organizations.

Epistemological character of the article is intentional and creates conceptual foundations for legitimizing the construction of theories based on the observed causal relationships, thus serving a stimulus for empirical analysis.

\section{Strategy and strategizing}

The essence of the strategy is dependent on the shift in the focus on different elements that are used to describe it, which is determined by the various epistemological, ontological and methodological assumptions of individual perspectives (Zakrzewska-Bielawska 2014, pp. 9-10). Despite frequent attempts to systematize it, this category remains a source of disputes and shifts of emphasis towards different areas of organization. As a part of the current discussion about its nature comes the concept of micro strategies and strategizing, according to which it is the ability of leaders to think in a manner which promotes the use of emerging opportunities, generates innovative growth and development of the organization. From the analysed point of view, the strategy should be defined as a situational, socially conditioned activity for which strategizing is actions, interactions and negotiations among multiple organisational actors (Calabrese, Costa 2015, p. 25). Following this, emphasis should be put on diverting attention from the core competence of the organization towards practical competence of strategists. This perspective focuses on managerial activity in the area of "strategy making", and thus sourcing ideas, positioning opportunities, identifying a variety of situations (Whittington 1996, p. 732). This process is much broader than the analysis of strategic direction, and its goal becomes the answer to the question: how do managers and consultants work across all strategic practices (Whittington

1 Strategy-as-Practice-International Network is an international network of approx. 3000 researchers and practitioners from around the world whose main purpose is to explain phenomena and laws governing modern strategic management, either from micro, or individual point of view. 
1996, p. 732), i.e. strategic planning, periodic review, strategic workshops and other related activities (Jarzembowski, Bologun, Seidl 2007, p. 8).

The foundation of the practical-theoretical approach is made up of three components and related questions (Jarzembowski, Bologun, Seidl 2007, p. 7):

- who is the strategic actor, influencing practice by means of its operation? (practitioner)

- what underlies their strategic decisions (practices)?

- how are strategic decisions made (praxis)?

These three elements: practitioners, practice and praxis are the foundations of the strategy-as-practice approach and are presented in the literature as a dichotomy of analysis of the levels of organization: Micro versus Macro (fig. 1).

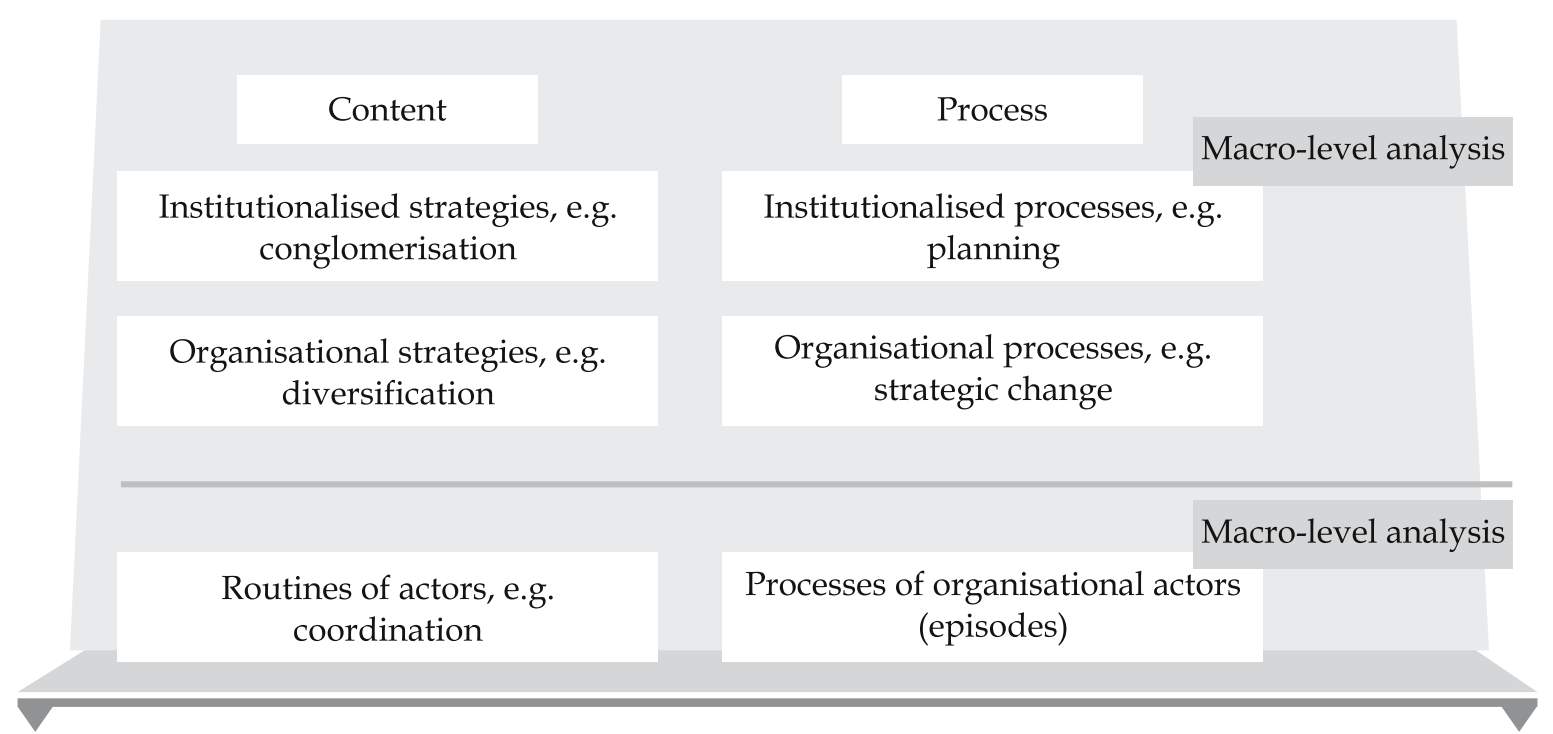

Figure 1. Macro and micro levels of analysis in the study of strategic management

Source: Based on: Paroutis, Heracleous, Angwin 2013, p. 6

Authors already mentioned G. Johnson, L. Melin and R. Whittington use the terms micro-strategy and strategizing to denote the "specific processes and practices that determine the daily activities of individuals, correlated with the strategic goals" (2004, p. 14), while at the same time consider these categories as identical.

Considerations were placed in the context of a changing environment in which opportunities are the basis for strategic decisions of management practitioners. Underlying them are personal characteristics of individuals, implemented in the 
decision-making path, based on the ongoing identification of opportunities in the environment of the organization.

\section{Context: opportunities and their market sources}

Redefining the strategy of an organization R. Krupski (2007, p. 5) put opportunities at its focal point. Given the considerable number of definitional perspectives of this category (Herron, Sapienza 1992; Krupski 2005, 2007 b) herein it will be understood as a situation that occurs both in the environment of an organisation and within it, arises from incomplete information ${ }^{2}$ of the other members of the community, and is based on individual perception, discovery and design of new opportunities, consequently taking the form of active strategic activities (Hunter 2013, p. 129). As a result of the use of market opportunities comes an increase of enterprise value (Wickham 2006 for: Hunter 2013, p. 134), often through new products, services, methods of production and work organization (Shane 2000, p. 451). The development of organization is determined by the ability to use them, resulting in faster, more efficient market operation than the competition (Eisenhardt, Martin 2000). In literature, factors most commonly associated with opportunity include: a) future economic value (potential for generating profit), b) novelty factor (a product, service or technology that did not exist before), and c) attractiveness (moral and formal appeal of the new product, service, technology, society) (Baron 2004 p. A1).

Situational nature of opportunities is determined by their sources. When analysing various typologies, and temporarily ignoring their endogenous and exogenous factors, it is worth quoting one by S. Trzcieliński (2011, pp. 58-59), who proposed a distinction between subjective and objective opportunities. The latter relate to events in the environment which are evident for many other market entities. They are dubiously desirable situations because they do not lead to the acquisition of unique and free strategic positions. The former, however, are identified only by a part of the environment, specifically by these organizations, whose individuals are aware of the existence of such a situations and can take appropriate actions to effectively take advantage of them. What becomes an und isputed source of opportunities is the environment

2 It might also be a lack of ability to see the causal relationship between a given situation and its consequences for the organization in the future. 
of the organization and, more specifically, the level of uncertainty generated by its particular ingredients versus the inside part of the organization, only vaguely described in literature. The other perspective consists in Schumpeter's new products and services through which estimating the probability of growth of the market value of the company becomes rather difficult (Hsieh, Nickerson, Zenger 2007, p. 1255). Interestingly, from the product and market perspective, these processes must occur simultaneously: identification of market opportunities and commercialization of products and services. When widening the scope of identification of opportunities, it should be emphasized that they do not relate only to immediate environment, but also emerge from the changes in the more distant: economic, technological, political, social and demographic environments, in the form of differentiators previously not acknowledged by organizational entities (Baron 2004, p. A4).

Connections of the organization with its market environment become crucial for the analysis of opportunity sources. From a strategic point of view, there are three types of relationships: a) cooperation, b) competition and c) coopetition (Stańczyk-Hugiet 2013, p. 74). The first is a relation in which it is possible to generate mutual benefits like increasing the efficiency of actions, easier achieving objectives and minimizing selfish behaviour. According to E. Stańczyk-Hugiet (2013, pp. 74-75) it is a type of relationship that enhances the chances of the emergence of new values, through the use of emerging opportunities. It is also connected with a lower risk and cost of introducing new or improved products on the market, increasing their dynamism and easier access to new markets (Eisenhardt, Schoonhoven 1996; quote: StańczykHugiet (2013, p. 75; Hagedoorn 1993; Kogut 1988; Wheelwright, Clark 1992). As a result of new organizational solutions occur processes of self-organization which accompany the realisation of joint business projects. This requires knowledge of mechanisms that allow to identify and seize the organizational opportunities (Stańczyk-Hugiet 2013, p. 76).

Competitor relations, especially those of a classic character, are based on cause-effect relationships between the organization and the elements of the competitive environment, in product and market categories. Porter's approach, however, does not reflect the complexity and multidimensionality of these relationships in a contemporary sense (Staczyk-Hugiet 2013, p. 82). Dynamic reflection of these relationships will involve the logic of the use of scarce resources (leverage logic) which are difficult to imitate or substitute, and thus highly valued commercially (Bingham, Eisenhardt 2008, p. 244), in combination with increased concentration of organizations in market 
niches. Such behaviour of modern organization shortens the life cycle of opportunities, and at the same time causes fierce competition for new possibilities for growth (opportunities). What emerges is thus an image of new object of competition on the markets, i.e. competition for opportunities. At least in the theoretical field. In practice, there is plenty evidence that product cannibalisation causes disregard of other possibilities of action (disruptive technologies) (Bower, Christensen 1995; Christensen, Overdorf 2000; Christensen, 2006; Sus 2013).

Coopetition is a relationship based on simultaneous cooperation and competition (Tsai 2002, p. 180), wherein all parties gain, making it is a positivesum game (Staczyk-Hugiet 2013, p. 84), although the literature also emphasises the neutral and negative role (Ritala 2012, p. 308). Without going into game theory and resource based view (RBV) origins of these relationships, motives of such actions must be emphasized. Empirical studies show that among the main premises of coopetition are the benefits of innovation and market development of companies. This means that through joint development of new solutions, companies seek reduction of uncertainty and risk, also in terms of product and market.

Each of these relationships determines uncertainty, which is also a source of organizational opportunity (table 1).

Table 1. Levels of environment uncertainty on different stages of relations

\begin{tabular}{|c|c|c|}
\hline $\begin{array}{l}\text { Type of } \\
\text { relationship }\end{array}$ & $\begin{array}{l}\text { Level of uncertainty in the } \\
\text { environment }\end{array}$ & Sources of opportunity \\
\hline Cooperation & $\begin{array}{l}\text { Minimized by increasing activities in } \\
\text { the area of knowledge sharing between } \\
\text { entities and diversity of points of view }\end{array}$ & $\begin{array}{l}\text { Negligible, due to greater focus of the } \\
\text { organization on the implementation } \\
\text { of joint, ongoing objectives rather than } \\
\text { searching for opportunities; attention } \\
\text { diverted from opportunities }\end{array}$ \\
\hline Coopetition & $\begin{array}{l}\text { Average; there is cooperation between } \\
\text { businesses, but on the other hand, there } \\
\text { are real chances of failure to cooperate, } \\
\text { which may involve an increase in } \\
\text { uncertainty } \\
\text { One of the motives, however, to take } \\
\text { this kind of cooperation is collective } \\
\text { reduction of uncertainty through the } \\
\text { sharing of costs and risks }\end{array}$ & $\begin{array}{l}\text { Average ability to identify opportunities, } \\
\text { with the focus on the complete lack of } \\
\text { this process, requires more attention } \\
\text { on observing cooperation within the } \\
\text { coopetition rather than actively seeking } \\
\text { new opportunities }\end{array}$ \\
\hline
\end{tabular}




\begin{tabular}{l|l|l} 
Competition & $\begin{array}{l}\text { High, uncertainty increases with the } \\
\text { intensity of competitive pressure, } \\
\text { which in turn reduces a possible } \\
\text { alternative actions }\end{array}$ & $\begin{array}{l}\text { Very likely, but rather in the form of } \\
\text { moving beyond the existing sector („,blue } \\
\text { ocean strategy") rather than seizing } \\
\text { opportunities positioning the company } \\
\text { Significantly ahead of the competition } \\
\text { increases with the possibility of inventive } \\
\text { and constructive opportunities }\end{array}$ \\
\hline
\end{tabular}

Source: own work based on: Courtney Kirkland, Viguerie 1997; Ritala 2012, pp. 307-324

In the analysed area of microfundations opportunities can be linked with the concept of bricolage proposed by C. Levi-Straus (1969, pp. 31-51). Since bricolage means do-it-yourself, and bricoleur is a DIY person, associations with practitioners and strategic practices are natural. Bricoleur is an individual engaged in a set of tasks assigned adequately to their competence, and using organizational slack (Wan Yiu 2009, p. 794), on which, however, they are not dependent. Bricoleur would rather focus on heterogeneous and ill-fitting to the currently executed plan, set of resources and materials, which is a result of accidental opportunities which arose (Levi-Straus 1969, pp. 31-32). Those sets are flexibly adapted to the current conditions according to the criterion of utility, but with limited application (Levi-Straus 1969, pp. 33-34). In the interpretation of this concept we can focus on performing tasks with the use of whatever is at hand, thus analysing the impact of organizational slack on organizational development (Bradley Shepherd, Wilklund 2011, p. 1072). However, this metaphorical approach to the formation of opportunity clearly emphasizes the role of man as the foundation of this process.

\section{Practitioners: cognitive foundations}

Identification of opportunity is partially a learning (cognitive) process, and therefore its effectiveness is dependent on psychological characteristics of the individual, resulting inter alia from their previous experience. Positioning the process of identifying opportunities in the area of microfundations is the same as the opinion of R.A. Baron (2004, p. A2), according to whom the process is dependent on the characteristics of individual practitioners: mental, emotional and cognitive structures, which result from their previous experience. In addition, researchers found that openness to experience (one of the determinants of activity in the area of opportunities, both on the market 
and endogenous) results from the human genome, a gene called DRD4 (Shane Nicolaou, Cherkas, Spector, 2010, p. 291). This feature is one of the five-factor model of personality, which also distinguishes such traits differentiating individuals as: openness to experience, imagination, curiosity and originality (Barrick, Mount 1991). People who have a high perception of experimentation are more open to new ideas, thoughts and unconventional perspective, and also tend to include external information more than those with a low perception of experimentation (Shane Nicolaou, Cherkas, Spector, 2010, p. 293). Such individuals are also more creative (Feist, 1998) as well as easier and faster to find new solutions to existing problems (Shane 2003). Creativity is directly related to imagination and may be defined as the ability to generate a large number of ideas to solve a defined problem (divergent / lateral thinking) (Myszkowski, Storme, Lubart 2015, p. 675), in the discussed case: ability to perceive the causal relationship between situations that are neither apparently related nor have the potential for development. Increasingly important are also heuristics that are shaping the key strategic processes, and constitute the backbone of dynamic organizational abilities ${ }^{3}$. Heuristics means individual ability to solve problems in a short time and with incomplete information (Eisenhardt, Furr, Bingham 2010, p. 1264). Limited time for decision-making is also a determinant of the use of intuition, a factor other than imagination, but equally as irrational (Stanczyk, Sus 2013; Sus 2016). An important trait of creative minds is the ability to think and communicate using creative metaphors, which allows individuals to take into account the existing context and consider the problem on multiple levels rather than in direct way, and even aggressively. Creators understand the imperative of complexity of the environment to the extent that they are able to work in the environment of not fully defined facts (Praszkier, Nowak 2012, pp. 145-146). Incomplete knowledge, in turn, leads to functioning in conditions of uncertainty.

3 Dynamic skills involve not so much streaming resources, but the mechanisms of learning and accumulating new skills and capabilities, and forces, which indicate the directions of these processes (Teece, Pisano, Shuen 1990, p. 11). Dynamic capabilities involve readiness to integrate, build and reconfigure internal and external competencies addressed to the suddenly changing environmental conditions in which these organizations operate (Teece, Pisano, Shuen 1997, pp. 509-533), whose primary sources should be sought in the micro-foundations. 


\section{Practitioners: behavioural uncertainty}

Environment uncertainty manifests itself in the inability to predict the effects of decisions or assess the events occurring in the environment (de Wit, Meyer 2007, p. 54-55). The ultimate filter for the information and stimuli from the environment is the human mind (Jędralska 2010, p. 9). The filtration process should be considered in temporal and causal (dynamic) dimensions. The first one identifies uncertainty as a category inherent in the future and the gap of knowledge involving incomplete diagnosis of an organization is called indeterminacy (Bojarski, 1984, pp. 160-162; quote: Jędralska 2010, p. 9-10). Another dimension takes the dynamic form, focused on "filling" the gaps of knowledge (cognitive dissonance) through active exploration and actively seeking new information (interactive search of opportunities).

However, it is not environmental but behavioural uncertainty that is the subject of these considerations (Kozielecki 1997, pp. 182-183). According to this concept, uncertainty in the mind of an individual results from internal (symptoms) and external (situational) factors. Internal uncertainty (inferred and introspective) results from cognitive limitations, qualities of mind, competence gap, whereas external uncertainty is the result of increased dynamics of elements of the environment and its complexity, adopting singular and distributive forms (Jędralska 2010, pp. 10-11), jointly constituting so-called „generalized uncertainty" (Koźmiński 2005, pp. 7-8).

From behavioural uncertainty stem two premises essential for the process of the formation of opportunities, which also constitute characteristics of their sources, namely (Jędralska 2010, p. 11):

- there has been a reduction in the time between stimuli coming from the environment and the actions inspired by them, thus creating one of the basic conditions of survival for today's organizations, i.e. the imperative of organizational flexibility; this is important information for practitioners, as it indicates a shorter duration time of market opportunities,

- increasing complexity of technology and associated with it growing complexity of management processes are important factors inhibiting the opportunity recognition processes; the sheer amount of information, or its overload, block the possibility of active observation of the environment, suppress the senses of workers and effectively makes them concentrate more on solving current problems, including the selection of mostly useless information.

Another important blocker in the opportunity identification process is limited cognitive, emotional and volitional resources of managers, resulting from the 
uncertainty, providing foundations for the theory of limited rationality of decisions and being a result of: a) limited ability to obtain information related to the W. Heisenberg uncertainty principle (1979, p. 133), which rejected the classical paradigm of determinism (Jędralska 2010, p. 12), substituting it with an indeterministic paradigm. The uncertainty principle denotes difficulties understanding the structural properties of the system and its dynamics, which is the result of focus on its static properties, or selected elements, while ignoring other, equally important ones; b) limited ability to process information resulting from the limitations of the human brain. The remedy to these problems increasingly consists in heuristic methods that facilitate and accelerate the decision-making process, while marginalising the quality of decisions; and c) limited capacity to store information, also associated with the specificity of the human brain (Jędralska 2010, p. 12). It seems, however, that the source of uncertainty is more a determinant of opportunity rather than an inhibitor, especially in the context of accumulation and development of knowledge.

\section{Conclusion}

Interest in the process of strategizing and its micro-foundations results from the fact that strategic management is constantly evolving, and so are changing the ways and forms of development, and commercialization of the effects of education (virtualization, faster access to knowledge and information). Placing the considerations in a dyad: individual characteristics of practitioners - determinant of environment dynamism in the form of opportunities, is only a fraction of the possibilities of interpretation, whose importance would be improved with empirical research. Nevertheless, worth emphasizing is the fact that classical opportunities known from the SWOT analysis, with new interpretations of strategy (micro-strategy) and strategizing, gain a more human dimension. It is not an organization which identifies and affects the formation of opportunity in the environment, but an individual who, being at the core of the process of re-anthropomorphisation of market entities, becomes responsible for their duration, growth or development.

\section{Summary}

\section{Strategizing in opportunities context}

This article attempts to draw attention to exploiting opportunities by strategists. The paper consists of four parts. The first one introduces the reader to the strategizing approach and macro- 
and micro-level strategic analysis. The second part presents opportunities and their sources, as a background for further considerations. The third part of the article concentrates on individual characteristics of strategic management practitioners, actively identifying new opportunities. The final part focuses on the issues of behavioural uncertainty, and so this type of uncertainty, which inhibits the process of using the opportunities by strategists.

Key words: strategizing, opportunity, micro-foundations, uncertainty, behaviourism.

\section{Streszczenie}

\section{Strategizowanie w kontekście okazji}

Celem artykułu jest próba zwrócenia uwagi na relacje zachodzące pomiędzy wykorzystywaniemokazjiprzezpodmiotyorganizacyjne, przy czym tym bytem indywidualnym staje się człowiek, a nie cała organizacja. Opracowanie składa się z czterech części. Pierwsza $\mathrm{z}$ nich wprowadza czytelnika $\mathrm{w}$ zagadnienia strategizowania oraz makro-i mikro-poziomów analizy strategicznej. Druga prezentuje kategorię okazji i ich źródeł, stanowiących kontekst na tle którego toczą się dalsze rozważania, związane $\mathrm{z}$ indywidualnymi cechami praktyków zarządzania strategicznego, czynnie identyfikujących okazje. To z kolei prezentuje część trzecia artykułu. Ostatnią część poświęcono zagadnieniom niepewności behawioralnej, a więc tego typu zjawiska, który hamuje proces wykorzystywania okazji przez strategów.

\section{Stowa}

kluczowe: strategizowanie, okazja, mikro-podstawy, niepewność, behawioryzm.

\section{References}

1. Barrick M.R., Mount M.K. (1991), The big five personality dimensions and job performance: a meta-analysis, „Personnel Psychology”, Vol. 44 (1).

2. Baron R.A. (2004), Opportunity recognition: a cognitive perspective, "Academy of Management Best Conference Paper", http://faculty. insead.edu/andersonp/VOBM_MAYJUN2005/Anderson \%20VOBM\%20 readings/Session $\% 202 \% 20$ How $\% 20$ venture $\% 20$ opportunites $\% 20$ are $\% 20$ screened/Baron,\% 202004.pdf; [access date: 15.01.2016].

3. Bingham Ch.B., EisenhardtK.M. (2008), Position, leverage and opportunity: 
a typology of strategic logics liking resources with competitive advantage, „Managerial and Decision Economics”, Vol. 29.

4. Bojarski W. (1984), Podstawy analizy i inżynierii systemów, PWN, Warszawa.

5. Bower J.L., Christensen C.M. (1995), Disruptive technologies: catching the wave, "Harvard Business Review", January-February.

6. Bradley S.W. , D.A. Shepherd, J. Wiklund, (2011), The importance of Slack for New Organizations Facing "Tough" Environment, "Journal of Management Studies", Vol. 48, Issue 5.

7. Calabrese A., Costa R. (2015), Strategic thinking and business innovation: Abduction as cognitive element of leader's strategizing, "Journal of Engineering and Technology Management", Vol. 38.

8. Christensen C.M., Overdorf M. (2000), Meeting the Challenge of Disruptive Change, "Harvard Business Review", March-April.

9. Christensen C.M. (2006), The ongoing process of building a theory of disruption," The Journal of Product Innovation Management", No. 23.

10. Courtney H. G., Kirkland J., Viguerie S. P. (1997), Strategy Under Uncertainty, "Harvard Business Review", November-December.

11. de Wit B., Meyer R. (2007), Synteza strategii, PWE, Warszawa.

12. Eisenhardt K.M., Schoonhoven C.B. (1996), Resource-based view of strategic Alliance formation: Strategic and social effects in entrepreneurial firms, "Organizational Science”, Vol. 7.

13. Eisenhardt K.M., Martin J.A. (2000), Dynamic capabilities: what are they?, "Strategic Management Journal”, Vol. 21.

14. Eisenhardt K.M., Furr N.R., Bingham Ch.B. (2010), Microfoundations of performance: balancing efficiency and flexibility in dynamic environments, "Organizational Science", Vol. 21, No. 6.

15. Feist G.J. (1998), A meta-analysis of personality in scientific and artistic creativity, "Personality and Social Psychology Review”, Vol. 2, Issue 4.

16. Hagedoorn J. (1993), Understanding the rationale of strategic technology partnering - interorganizational modes of cooperation and sectoral differences, „Strategic Management Journal”, Vol. 14.

17. Heisenberg W. (1979), Ponad granicami, Państwowy Instytut Wydawniczy, Warszawa.

18. Herron L., H.J. Sapienza (1992), The entrepreneur and the initiation of new venture launch activities, "Entrepreneurship Theory and Practice”, Vol. 16.

19. Hsieh Ch., Nickerson J.A., Zenger T.R. (2007), Opportunity Discovery, Problem Theory and a Theory of the Entrepreneurial Firm, "Journal of Management Studies", Vol. 44, Issue 7.

20. Hunter M. (2013), A Typology of Entrepreneurial Opportunity, „Economics, Management, and Financial Markets”, Vol. 8, Issue 2. 
21. Jarzebowski P., Balogun J., Seidl D. (2007), Strategizing: The challenges of a practice perspective, „Human Relations”, Vol. 60, Issue 1.

22. Jędralska K. (red.) (2010), Zarządzanie niepewnością, Prace Naukowe Akademii Ekonomicznej im. Karola Adamieckiego w Katowicach, Katowice.

23. Johnson G., Melin L., Whittington R. (2003), Micro strategy and strategizing: Towards an activity-based view, "Journal of Management Studies", Vol. 40, Issue 1.

24. Kogut B. (1988), Joint ventures: Theoretical and empirical perspectives, "Strategic Management Journal”, Vol. 9.

25. Kozielecki J. (1997), Koncepcje psychologiczne człowieka, Wydawnictwo Akademickie Żak, Warszawa.

26. Koźmiński A.K. (2005), Zarządzanie w warunkach niepewności. Podręcznik dla zaawansowanych, PWE, Warszawa.

27. Krupski R. (red.) (2005), Zarządzanie przedsiębiorstwem w turbulentnym otoczeniu. Ku superelastycznej organizacji, PWE, Warszawa.

28. Krupski R. (2007), Redefiniowanie strategii organizacji, „Przegląd Organizacji, No. 3.

29. Lévi-Strauss C. (1969), Myśl nieoswojona, PWN, Warszawa.

30. Myszkowski N., Storme M., Lubart A.D.T. (2015), Managerial creative problem solving and the Big Five personality traits, "Journal of Management Development", Vol. 34, Issue 6.

31. Paroutis S., L. Heracleous, D. Angwin (2013), Practicing Strategy: Text and Cases, http://www2.warwick.ac.uk/fac/soc/wbs/subjects/sib/ people/sotirios_profile/53647_paroutis_chapter_one.pdf [access date: 10.01.206]

32. Praszkier R., Nowak A. (2012), Przedsiębiorczość społeczna. Teoria i praktyka, Wyd. Oficyna a Wolters Kluwer business, Warszawa.

33. Ritala P. (2012), Coopetition Strategy - When is it Successful? Empirical Evidence on Innovation and Market Performance, „British Journal of Management", Vol. 23.

34. Shane S. (2000), Prior Knowledge and the Discovery of Entrepreneurial Opportunities, "Organization Science”, Vol. 11, No. 4.

35. Shane S. (2003), A general theory of entrepreneurship: The individualopportunity nexus, Edward Elgar, Cheltenham.

36. Shane S., Nicolaou N., Cherkas L., Spector T.D. (2010), Do openness to experience and recognizing opportunities have the same genetic source?, "Human Resource Management", Vol. 49, No. 2.

37. Stańczyk S., Sus A. (2013), Intuicja w zarządzaniu, „Organizacja i Zarządzanie", No. 1147, Zeszyty Naukowe Politechniki Łódzkiej, Wydawnictwo Politechniki Łódzkiej, Łódź.

38. Stańczyk-Hugiet E. (2013), Dynamika strategiczna w ujęciu ewolucyjnym, Wydawnictwo Uniwersytetu Ekonomicznego we Wrocławiu, Wrocław. 
39. Sus A. (2013), Kluczowe czynniki sukcesu strategii współczesnych organizacji, „Zarządzanie i Finanse”, Vol. 11, No. 4, Part I.

40. Sus A. (2016), Paradoksy współczesnej strategii. Racjonalizm versus irracjonalizm, Wrocław in press.

41. Teece D.J., Pisano G., Shuen A. (1990), Firm capabilities, resources and the concept of strategy, „Economic Analysis and Policy Working Paper EAP 38", Mimeo/University of California at Berkeley/Haas School of Business, New York/Berkeley.

42. Teece D.J., Pisano G., Shuen A. (1997), Dynamic capabilities and strategic management, "Strategic Management Journal”, Vol. 18.

43. Thoms P., K.S. Moore, Scott K. S. (1996), The Relationship between SelfEfficacy for Participating in Self-Managed Work Groups and the Big Five Personality Dimensions, „Journal of Organizational Behavior", Vol. 17, No. 4.

44. Tsai W. (2002), Social Structure of "Coopetition" Within a Multiunit Organization: Coordination, Competition, and Intraorganizational Knowledge Sharing, „Organization Science”, Vol. 13, No. 2.

45. Trzcieliński S. (2011), Przedsiębiorstwo zwinne, Wydawnictwo Politechniki Poznańskiej, Poznań.

46. Wan W., W., Yiu D. W. (2009) From crisis to opportunity: environmental jolt, corporate acquisitions, and firm performance, „Strategic Management Journal", Vol. 30.

47. Wheelwright S.C., Clark K.B. (1992), Creating project plans to focus product development, „Harvard Business Review”, Vol. 70.

48. Wickham P.A. (2006), Strategic Entrepreneurship, 4th ed., Prentice Hall, New York.

49. Whittington R. (1996), Strategy as Practice, „Long Range Planning”, Vol. 29, No. 5.

50. Whittington R., Johnson G., Melin L. (2004), The emerging field of strategy practice: some links, a trap, a choice and a confusion, Paper presented at the European Group for Organization Studies Conference, Ljubljana.

51. Zakrzewska-Bielawska A. (2014), Ewolucja szkół strategii: przegląd głównych podejść i koncepcji, [in:] R. Krupski (ed.), Zarządzanie strategiczne. Rozwój koncepcji i metod, Prace Naukowe Wałbrzyskiej Wyższej Szkoły Zarządzania i Przedsiębiorczości, No. 27, (2), Wałbrzych. 